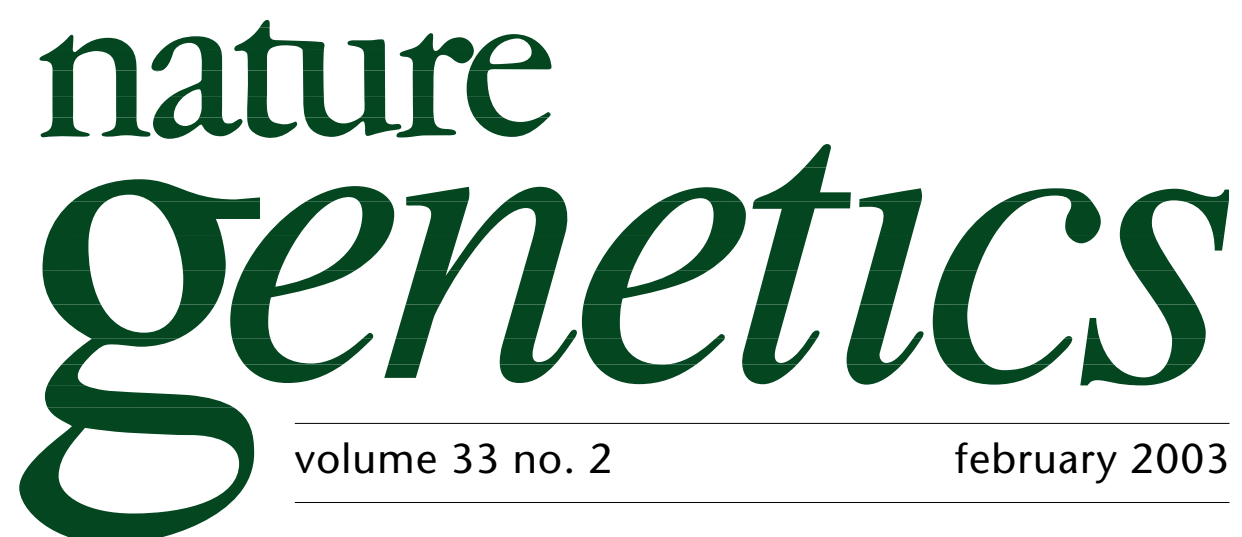

\title{
From Cambridge to Srebrenica
}

In his introduction to the Norton critical edition of James Watson's The Double Helix (that "tactless and truly remarkable book," in Alex Comfort's words), Gunther Stent wrote of learning in a high school history class that the Renaissance began precisely on 29 May 1453, with the fall of Constantinople. "On that date, so I thought, everybody suddenly found out that the Middle Ages were over...”. The commemorations and celebrations to mark the 50th anniversary of the discovery of the double helical structure of DNA have now begun in earnest, and although the precise anniversary is not quite so hard to discern as that of the rediscovery of antiquity, a monthly journal is faced with a decision: is it in February (the key insight), or March (the theoretical elaboration), or April (publication)?

As a journal, of course, we place great importance on publication dates, and as such we will have more to say about the anniversary in April, along with a series of special commentaries to be published in that issue. There is no denying, however, that it was on 28 February 1953 that Watson hit on the idea of purine-pyrimidine base pairing, launching himself and Francis Crick on the model-building exercise that would culminate in their note to Nature being published not quite two months later.

For now, there is much in the news that reminds us of how much the world has been changed by the body of work on the molecular mechanisms of inheritance that commenced in the spring of 1953 . For geneticists, the changes are overwhelming enough to generate amazement when compared with the state of the science a half-century ago, an era that is still part of living memory. In the wider world, the changes are equally as profound, but perhaps most notably so in ways that could not have been foreseen.

The annual symposium of the American Academy of Forensic Science will convene this month in Chicago. A recent news report noted that the staff of Gordon Bacon will present a record 18 papers at the meeting. Who is Gordon Bacon? A former British homicide detective, Mr. Bacon is now chief of staff of the International Commission on Missing Persons (ICMP), an organization established in 1996 to assist families in determining the fates of missing loved ones in the wake of the conflicts in the former Yugoslavia. Estimates put the number of the missing in Bosnia and Herzegovina at close to 30,000. What Mr. Bacon and his colleagues will be describing in Chicago is their recent success in establishing the identities of a large number of these individuals-as of last November, an ICMP press release put the number of positive DNA matches at more than 1,200, with 200 new matches made every month. Such success is unprecedented in forensic science, and similar approaches have been and are being used to identify victims of the attacks on the World Trade Center. 
Nucleic acid-based forensics is, of course, well known for its impact on the criminal justice system where, provided sufficient funds are available, it frequently helps to convict the guilty and free the innocent. Its application to the larger challenge of the horrific crimes committed in the Bosnian city of Srebrenica and in New York has required advances in the chemistry of DNA extraction and the molecular biology and bioinformatics of genotyping. Standard genotyping requires large genomic segments for the analysis of a panel of short tandem repeats. In New York, the recovery of small, unusable fragments of DNA from nuclei prompted an effort by Celera Genomics and Applied Biosystems to attempt extraction and amplification of mitochondrial DNA, which has met with some success. Another potentially promising approach has been that of Orchid BioSciences, which has used high-throughput profiling of single-nucleotide polymorphisms. This method has the advantage of making even short stretches of DNA useful in identification.

With continued work (and funding), it seems likely that most, if not all, of the families awaiting word of the missing and the dead will have answers. Reading about the gratitude of those who have already received some solace suggests that this is no small accomplishment. But what does this say about how far we've come from 1953? That genetics is covered so widely in the popular press has something to do with the reasonable assumption that it has, and will continue to have, a tangible effect on human health, in a way that a discipline like astronomy, however important as a field of study, does not. And yet the impact of genetics on medicine, though fully in our sights, is still in its infancy, despite the enormous effort that has been made to speed its integration into clinical practice. Is it not ironic, then, that the grim application of molecular biology (the 'secret of life') to forensics is part of a very short list of instances where the field affects the lives of a large number of people on a daily basis?

After all, although DNA sequencing and PCR are essential tools of forensic scientists, all of these technologies are ultimately based on the fundamental sequence-specific hybridization of purines with pyrimidines. And on killing fields around the world, this fact can offer to grieving people one simple gift: the sure knowledge that a loved one was here, in this place. We are more than the product of our genes, the saying goes. But we are in part our genes, and the application of that knowledge to identify the lost is one important reason why the discovery of the structure of DNA rightfully has pride of place in the history of twentieth-century science.

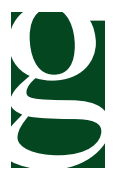

